\title{
Cytotoxicity Brine Shrimp Activity of Leptadenia Hastata (PER) Decne Leaves, Stem-Bark and Root Extract
}

\author{
Umaru IJ ${ }^{1,2 *}$, Badruddin FA ${ }^{1}$ and Umaru $\mathrm{HA}^{3}$ \\ ${ }^{1}$ Faculty of Resource Science and Technology, University of Malaysia Sarawak, \\ Malaysia \\ ${ }^{2}$ Department of Biochemistry, Federal university Wukari, Nigeria \\ ${ }^{3}$ Department of Biochemistry, Modibo Adama University of Technology, Nigeria
}

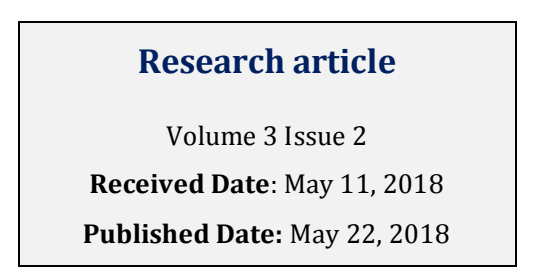

*Corresponding author: Isaac John Umaru, Faculty of Resource Science and Technology, University of Malaysia Sarawak, Kuching, 94300, Kota Samarahan Malaysia, Tel: 168395004; Email: umaruisaac@gmail.com

\section{Abstract}

Objective: The present study was conducted to test for in vivo Brine Shrimp Cytotocity activity of Leptadenia hastata leaves, stem-bark and root extracts after successive maceration in five solvents (n-hexane, dichloromethane (DCM) ethyl acetate chloroform and methanol) and correlate cytotoxicity results with known pharmacological activities of the plant.

Methods: Cytotoxicity was evaluated in terms of $\mathrm{LC}_{50}$ (lethality concentration), 10 nauplii were added into three replicates of each concentration of the plant extracts, and after $24 \mathrm{~h}$ the surviving brine shrimp larvae were counted, and $\mathrm{LC}_{50}$ was assessed.

Results: Potent cytotoxicity was found for both the leaves, stem-bark and root extracts of Leptadenia hastata, results showed a concentration dependent increment in mortality rate of the brine shrimp nauplii and the n-hexane dichloromethane ethyl acetate, chloroform and methanol fractions of the leaves, stem-bark and root extracts were potent against the brine shrimp, with chloroform Leaf extract having the highest 3460.00 and Methanol as the lowest $\mathrm{LC}_{50}$ with 651.292 .

Conclusion: The result indicated that bioactive components are present in these plants that could be accounted for its pharmacological effects. Thus, the results support the uses of these plant species in traditional medicine.

Keywords: Brine shrimp; Cytotoxicity; Leptadenia hastate; Crude extract

\section{Introduction}

The lethality of a test sample in a simple zoological organism such as the Brine shrimp (Artemia salina) has been utilized by Meyer, et al. [1] in the Brine Shrimp Cytotoxicity Test. It is a very useful tool to screen a wide range of chemical compounds for their various bioactivities [2]. This method has become an attractive pre-screen for such activities as it is relatively simple and inexpensive to test large numbers of crude plant extracts in a very short time. Most surveys of this type have been carried out on traditional medicinal plants of 


\section{International Journal of Biochemistry \& Physiology}

various parts around the world [3-6]. Thus Leptadenia hastate, Leptadenia hastata is an edible nondomesticated valuable herb with creeping latex stems, glabescent leaves, glomerulus and racemes flowers as well as follicle fruits. It is typically grown in tropical dry lands in sandy soil. It is a well utilized plant in Africa. In Chad, the roots are used to treat scabies [7]. This plant is commonly used in Nigeria as spice and as sauces in Hausa speaking communities as well as Higgi community in Michika Adamawa state [8,9]. Also the local healers use the plant for hypertension, catarrh and skin diseases [10]. In Burkina Faso, it used locally for sexual potency by chewing the leaves. Decoction of the leaves is used in the treatment of trypanosomosis. It is also useful in the treatment of skin diseases and in wound-healing by the application of its latex. The plant is known to have effective antifungal and antibacterial properties [9].

\section{Materials and Methods}

\section{Sample Collection}

Fresh leaves, stem-bark and roots of Leptadenia hastata were obtained from Michika Local Government Adamawa state Nigeria. Identification of plants was done through herbarium available in the Ahmadu Bello University Zaria. The plants collected were washed with distilled water to remove the soil and dust particles.

\section{Extraction Procedure}

The freshly dried leaves, stem-bark and the root of Leptadenia hastata were grounded into powdered forms using laboratory grinder machine (FGR-350, Quest Scientific), serial extraction was done using five different solvent systems (n-hexane, dichloromethane, ethyl acetate, chloroform and methanol. $100 \mathrm{~g}$ of the powdered samples was weighed into an Erlenmeyer flask and each solvent (three times the weight of the extracts) was added, the solutions were covered and shaken at a time interval of an hour and then allow to stand for 7 days at room temperature. The mixtures were then filtered using Whatman filter paper No.4 and the solvent was evaporated using a rotary evaporator (Heidolph Laborato 400) under reduced pressure below $60^{\circ} \mathrm{C}$.

\section{Hatching of Brine Shrimp}

The brine shrimp hatch, $1.5 \mathrm{~g}$ of Artemia salina cysts (Sanders Great Salt Lake, Brine Shrimp Company U. S. A.) was aerated in 1 L capacity glass container containing filtered seawater (collected from Damai beach in Kuching-Sarawak). Air pump was fitted to the water to ensure complete aeration of the cysts after 48 hrs of incubation at room temperature between 27$29^{\circ} \mathrm{C}$ under continuous illumination of fluorescence lamp, newly hatched free-swimming nauplii were harvested from the bottom of the glass container. The freshly hatched nauplii were used for the bioassay.

\section{Preparation of Test Samples}

An alternative dilution procedure developed by McLaughlin, et al. [1]. was adopted in the preparation of different dilution of the plant extracts, $4 \mathrm{mg}$ of each extract was dissolved in $200 \mu \mathrm{l}$ of DMSO (RCI Labscan limited) and a lower series of chosen concentration was prepared by serial dilution with DMSO. The assay system was prepared with $5 \mathrm{ml}$ of filtered seawater containing chosen concentration of extract and 1\% yeast extract (for feeding) in a pre-marked 6-well microplate and 10 brine shrimps were carefully taken with a micropipette and introduced into each microplate, this was done in triplicates making a total of 30 brine shrimps per concentration. In this study DMSO (Dimethyl sulfuroxide) and sea water was used as the negative control while thymol was used as positive standard (+ve). Filtered seawater was added to DMSO in a set of 3 pre-marked 6-well microplate and 10 brine shrimps were carefully taken with a micropipette and introduced into each microplate, this was used as the (ve) control groups.

If the brine shrimp in these microplates shows a rapid mortality rate, then the test is considered invalid as the nauplii might have died due to some reasons other than the cytotoxicity of the extracts. The setup was allowed to remain for $24 \mathrm{hrs}$ under constant illumination of fluorescent and number of survived nauplii were counted with a hand lens, from the data the average death of the brine shrimp at different concentrations of the extract and the $\mathrm{LC}_{50}$ of the plant was calculated using probit regression by statistical software SPSS 22 and the result was expressed as mean+SEM at the $95 \%$ level of confidence $(\mathrm{p}<0.05)$.

\section{Result and Discussion}

\section{Result}

The lethality concentration of $\mathrm{LC}_{50}$ was assessed at $95 \%$ confidence using probit analysis. it has been observed $\mathrm{LC}_{50}$ value of less than $1000 \mu \mathrm{g} / \mathrm{mL}$ is toxic while $\mathrm{LC}_{50}$ value of greater than $1000 \mu \mathrm{g} / \mathrm{mL}$ is nontoxic [1]. The tables show the average death of Artemia salina at different concentration of five crude extracts of Leptadenia hastata. In this study DMSO (Dimethyl sulfuroxide) and sea water was used as the negative control while thymol was used as positive standard which the $\mathrm{LC}_{50}$ value against brine shrimp was $1.16 \mu \mathrm{g} / \mathrm{mL}$. The average death of Artemia salina at different concentration of Leptadenia hastata after $24 \mathrm{hrs}$ is shown in the tables below. Figure 1-5, displayed the percentage (\%) of the brine shrimp death against Leptadenia hastata crude extract concentration. Analysis of the crude extract to determined their 


\section{International Journal of Biochemistry \& Physiology}

toxicity against the brine shrimp demonstrated that Leptadenia hastata solvents concentration gave weak cytotocity with $\mathrm{LC}_{50}$ as shown in the following tables;

\begin{tabular}{|c|c|c|c|c|c|c|c|}
\hline \multirow{3}{*}{$\begin{array}{l}\text { Hexane Crude } \\
\text { extract }\end{array}$} & \multicolumn{6}{|c|}{ Average death of Artemia salina } & \multirow{3}{*}{ LC50 $(\mu \mathrm{g} / \mathrm{mL})$} \\
\hline & \multicolumn{6}{|c|}{ Concentration $(\mu \mathrm{g} / \mathrm{mL})$} & \\
\hline & $\mathbf{1}$ & 10 & 25 & 50 & 100 & 500 & \\
\hline Leaves & $0.33 \pm 0.58$ & $1.00 \pm 0.00$ & $1.33 \pm 0.58$ & $2.00 \pm 1.00$ & $2.00 \pm 1.00$ & $2.67 \pm 0.58$ & 9421.49 \\
\hline Stem-bark & $0.00 \pm 0.00$ & $0.67 \pm 0.58$ & $1.00 \pm 0.00$ & $0.33 \pm 0.58$ & $1.33 \pm 0.58$ & $1.47 \pm 0.58$ & 4657.358 \\
\hline Roots & $0.00 \pm 0.00$ & $0.67 \pm 0.58$ & $1.00 \pm 0.00$ & $0.33 \pm 0.58$ & $1.33 \pm 0.58$ & $1.67 \pm 0.58$ & 4657.358 \\
\hline (-ve control) & 0 & 0 & 0 & 0 & 0 & 0 & - \\
\hline (+ve control) & $5 \pm 0.57$ & $7 \pm 0.58$ & $10 \pm 0.00$ & $10 \pm 0.00$ & $10 \pm 0.00$ & $10 \pm 0.00$ & 1.16 \\
\hline
\end{tabular}

Table 1: Average death of Artemia salina at different concentration of hexane crude extract of Leptadenia hastata Leaf-bark and Stem, Roots.

The result is mean+SD. $\mathrm{N}=30$, table 1 . Above show the average death and $\mathrm{LC}_{50}$ of Artemia salina brine shrimp at different concentration of the hexane Leaf, stem-bark and roots extract of Leptadenia hastata.



Figure 1: Average death of Artemia salina (\%) as a function of various hexane extract concentration on plant parts of Leptadenia hastate was monitored after $24 \mathrm{hrs}$ exposure of different concentration of the plant parts.

\begin{tabular}{|c|c|c|c|c|c|c|c|}
\hline \multirow{3}{*}{$\begin{array}{c}\text { Dichloromethane } \\
\text { extract }\end{array}$} & \multicolumn{6}{|c|}{ Average death of Artemia salina } & \multirow{3}{*}{$\mathrm{LC50}(\mu \mathrm{g} / \mathrm{mL})$} \\
\hline & \multicolumn{6}{|c|}{ Concentration $(\mu \mathrm{g} / \mathrm{mL})$} & \\
\hline & 1 & 10 & 25 & 50 & 100 & 500 & \\
\hline Leave & $0.00 \pm 0.00$ & $1.33 \pm 1.16$ & $1.33 \pm 0.58$ & $2.00 \pm 1.00$ & $2.67 \pm 0.58$ & $1.00 \pm 1.00$ & 1419.4 \\
\hline Stem-bark & $0.00 \pm 0.00$ & $0.00 \pm 0.00$ & $1.33 \pm 0.58$ & $1.67 \pm 0.58$ & $2.67 \pm 1.15$ & $3.33 \pm 0.58$ & 1500.229 \\
\hline Roots & $0.00 \pm 0.00$ & $1.00 \pm 0.00$ & $1.33 \pm 0.58$ & $1.67 \pm 0.58$ & $2.67 \pm 1.15$ & $3.33 \pm 0.58$ & 1500.23 \\
\hline (-ve control) & 0 & 0 & 0 & 0 & 0 & 0 & - \\
\hline (+ve control) & $5 \pm 0.57$ & $7 \pm 0.58$ & $10 \pm 0.00$ & $10 \pm 0.00$ & $10 \pm 0.00$ & $10 \pm 0.00$ & 1.16 \\
\hline
\end{tabular}

Table 2: Average death of Artemia salina at different concentration of dichloromethane crude extract of Leptadenia hastata Leaf-bark and Stem, Roots.

The result is mean+SD. $\mathrm{N}=30$, table 1 . Above show the average death and $\mathrm{LC}_{50}$ of Artemia salina brine shrimp at different concentration of the dichloromethane Leaf, stem-bark and roots extract of Leptadenia hastata. 


\section{International Journal of Biochemistry \& Physiology}



Figure 2: Average death of Artemia salina (\%) as a function of various Dichloromethane extract concentration on plant parts of Leptadenia hastata was monitored after $24 \mathrm{hrs}$ exposure of different concentration of the plant parts.

\begin{tabular}{|c|c|c|c|c|c|c|c|}
\hline \multirow{3}{*}{$\begin{array}{l}\text { Ethyl acetate } \\
\text { Crude extract }\end{array}$} & \multicolumn{6}{|c|}{ Average death of Artemia salina } & \multirow{3}{*}{ LC50 $(\mu \mathrm{g} / \mathrm{mL})$} \\
\hline & \multicolumn{6}{|c|}{ Concentration $(\mu \mathrm{g} / \mathrm{mL})$} & \\
\hline & 1 & 10 & 25 & 50 & 100 & 500 & \\
\hline Leaves & $0.00 \pm 0.00$ & $0.00 \pm 0.00$ & $0.33 \pm 0.58$ & $0.33 \pm 0.58$ & $1.00 \pm 1.00$ & $1.00 \pm 0.002$ & 821.103 \\
\hline Stem-bark & $0.00 \pm 0.00$ & $0.67 \pm 0.00$ & $1.67 \pm 1.53$ & $3.00 \pm 0.00$ & $3.33 \pm 0.58$ & $3.33 \pm 0.58$ & 833.774 \\
\hline Roots & $0.00 \pm 0.00$ & $0.57 \pm 0.00$ & $1.67 \pm 1.53$ & $3.00 \pm 0.00$ & $3.13 \pm 0.58$ & $3.33 \pm 0.58$ & 813.8 \\
\hline (-ve control) & 0 & 0 & 0 & 0 & 0 & 0 & - \\
\hline (+ve control) & $5 \pm 0.57$ & $7 \pm 0.58$ & $10 \pm 0.00$ & $10 \pm 0.00$ & $10 \pm 0.00$ & $10 \pm 0.00$ & 1.16 \\
\hline
\end{tabular}

Table 3: Average death of Artemia salina at different concentration of Ethyl acetate crude extract of Leptadenia hastata Leaf, Stem-bark and Roots.

The result is mean+SD. $\mathrm{N}=30$, table 1 . Above show the average death and $\mathrm{LC}_{50}$ of Artemia salina brine shrimp at different concentration of the ethyl acetate Leaf, stem-bark and roots extract of Leptadenia hastata.

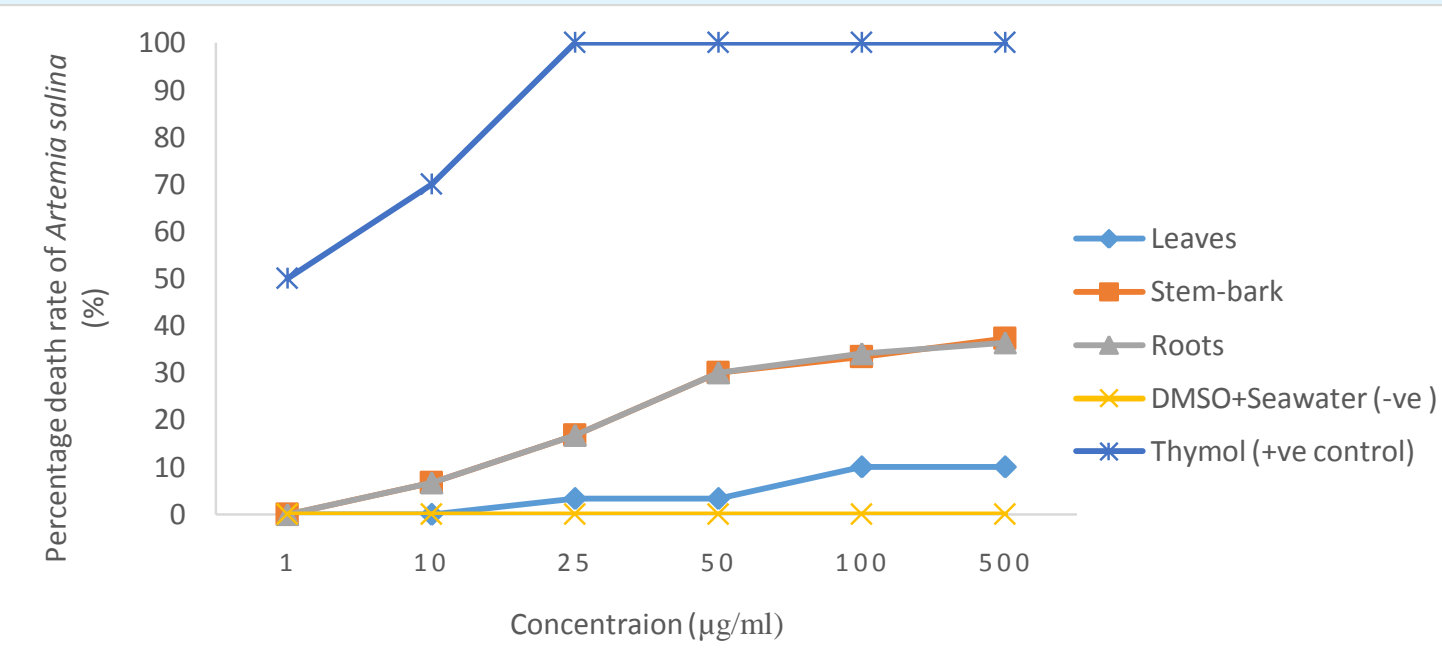

Figure 3: Average death of Artemia salina (\%) as a function of various ethyl acetate extract concentration on plant parts of Leptadenia hastate was monitored after $24 \mathrm{hrs}$ exposure of different concentration of the plant parts. 


\section{International Journal of Biochemistry \& Physiology}

\begin{tabular}{|c|c|c|c|c|c|c|c|}
\hline \multirow{3}{*}{$\begin{array}{c}\text { Chloroform } \\
\text { Crude } \\
\text { extract }\end{array}$} & \multicolumn{6}{|c|}{ Average death of Artemia salina } & \multirow{3}{*}{ LC50 $(\mu \mathrm{g} / \mathrm{mL})$} \\
\hline & \multicolumn{6}{|c|}{ Concentration $(\mu \mathrm{g} / \mathrm{mL})$} & \\
\hline & 1 & 10 & 25 & 50 & 100 & 500 & \\
\hline Leaves & $1.00 \pm 0.01$ & $1.00 \pm 0.56$ & $2.00 \pm 0.00$ & $2.00 \pm 0.56$ & $2.00 \pm 0.00$ & $3.00 \pm 0.00$ & 3460 \\
\hline Stem-bark & $0.33 \pm 0.58$ & $0.67 \pm 0.58$ & $1.00 \pm 0.00$ & $1.33 \pm 0.58$ & $2.33 \pm 0.58$ & $4.33 \pm 0.58$ & 813.96 \\
\hline Roots & $0.33 \pm 0.58$ & $0.67 \pm 0.58$ & $1.00 \pm 0.00$ & $1.33 \pm 0.58$ & $2.33 \pm 0.58$ & $4.34 \pm 0.58$ & 803.69 \\
\hline (-ve control) & 0 & 0 & 0 & 0 & 0 & 0 & - \\
\hline (+ve control) & $5 \pm 0.57$ & $7 \pm 0.58$ & $10 \pm 0.00$ & $10 \pm 0.00$ & $10 \pm 0.00$ & $10 \pm 0.00$ & 1.16 \\
\hline
\end{tabular}

Table 4: Average death of Artemia salina at different concentration of chloroform crude extract of Leptadenia hastata Leaf Stem-bark and Roots.

The result is mean+SD. $\mathrm{N}=30$, table 1 . Above show the average death and $\mathrm{LC}_{50}$ of Artemia salina brine shrimp at different concentration of the chloroform Leaf, stem-bark and roots extract of Leptadenia hastata.

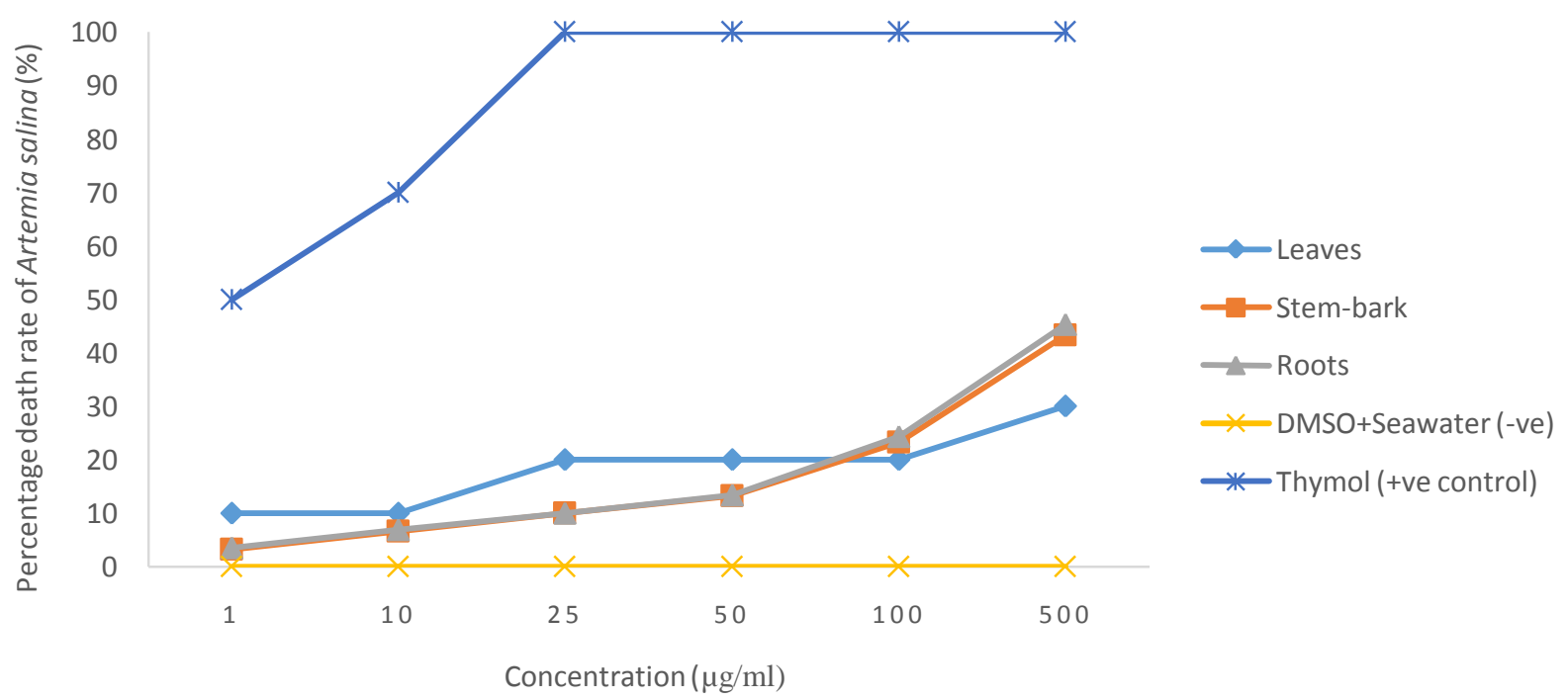

Figure 4: Average death of Artemia salina (\%) as a function of various Chloroform extract concentration on plant parts of Leptadenia hastate was monitored after $24 \mathrm{hrs}$ exposure of different concentration of the plant parts.

\begin{tabular}{|c|c|c|c|c|c|c|c|}
\hline \multirow{3}{*}{$\begin{array}{c}\text { Methanol Crude } \\
\text { extract }\end{array}$} & \multicolumn{6}{|c|}{ Average death of Artemia salina } & \multirow{3}{*}{$\mathrm{LC50}(\mu \mathrm{g} / \mathrm{mL})$} \\
\hline & \multicolumn{6}{|c|}{ Concentration $(\mu \mathrm{g} / \mathrm{mL})$} & \\
\hline & 1 & 10 & 25 & 50 & 100 & 500 & \\
\hline Leaves & $1.00 \pm 0.00$ & $1.33 \pm 0.58$ & $1.33 \pm 0.58$ & $2.00 \pm 0.00$ & $1.67 \pm 0.58$ & $1.33 \pm 0.73$ & 651.292 \\
\hline Stem-bark & $0.00 \pm 0.00$ & $0.33 \pm 0.58$ & $1.33 \pm 0.58$ & $2.67 \pm 0.58$ & $2.67 \pm 0.58$ & $1.48 \pm 1.40$ & 992.985 \\
\hline Roots & $0.00 \pm 0.00$ & $0.23 \pm 0.58$ & $1.23 \pm 0.58$ & $2.57 \pm 0.58$ & $2.57 \pm 0.58$ & $1.48 \pm 1.40$ & 952.955 \\
\hline (-ve control) & 0 & 0 & 0 & 0 & 0 & 0 & - \\
\hline (+ve control) & $5 \pm 0.57$ & $7 \pm 0.58$ & $10 \pm 0.00$ & $10 \pm 0.00$ & $10 \pm 0.00$ & $10 \pm 0.00$ & 1.16 \\
\hline
\end{tabular}

Table 5: Average death of Artemia salina at different concentration of methanol crude extract of Leptadenia hastata Leaf-bark and Stem, Roots.

The result is mean+SD. $\mathrm{N}=30$, table 1 . Above show the average death and $\mathrm{LC}_{50}$ of Artemia salina brine shrimp at different concentration of the methanol Leaf, stem-bark and roots extract of Leptadenia hastate. 


\section{International Journal of Biochemistry \& Physiology}



Figure 5: Average death of Artemia salina (\%) as a function of various Methanol extract concentration on plant parts of Leptadenia hastatawas monitored after $24 \mathrm{hrs}$ exposure of different concentration of the plant parts.

\section{Discussion}

The results of the brine shrimp lethality assay are shown in Tables 1-5, the solvent extracts at different concentration of the three plant parts of Leptadenia hastata tested showed a good brine shrimp Larvicidal activity. The lethality concentration $\left(\mathrm{LC}_{50}\right.$ of the leaves, stem-bark and the roots extracts were 1, 10, 25, 50, 100, and $500 \mathrm{ppm}(\mu \mathrm{g} / \mathrm{mL})$ respectively. The degree of lethality was directly proportional to the concentration of the extracts in all the plant parts. Maximum mortalities were observed at the concentration of the extract 500ppm in all the plant parts (leaves, stem-bark and the roots). Based on the results, the brine shrimp lethality of the plant parts was found to be concentration-dependent. However, the observed lethality of the three parts extracts to brine shrimps indicated the presence of potent cytotoxic and probably antitumor components.

The average death of Artemia salina at different concentration of hexane crude extract of Leptadenia hastata Leaf, Stem-bark and Roots in table 1, indicated cytotocity against brine shrimp with $\mathrm{LC}_{50}$ values of 942.149, 4657.358, and 4657.358 respectively for hexane extract. The average death of brine shrimp for leaf extract was slightly higher with $\mathrm{LC}_{50}$ value of 942.149 when compared with the stem-bark and the roots. At higher concentration of $500 \mu \mathrm{g} / \mathrm{mL}$ the leaves caused the death of the brine shrimp at an average of $26.7 \%$ while the stem-back and the roots was $14.7 \%$ and $16.7 \%$ respectively at the same concentration. It was observed that the concentration dependent increment of hexane extracts of the plant parts mortality rate of brine shrimp provides a proof of nontoxic of the hexane extract of the plant Leptadenia hastata.

However, the concentration of Dichloromethane crude extract of L. hastata Leaf, Stem-bark and Roots, showed less cytotoxicity against brine shrimp with $\mathrm{LC}_{50}$ values of $1419.40,1500.229$ and 1500.230 greater than $1000 \mu \mathrm{g} / \mathrm{mL}$ respectively. The leaf caused an average of $10 \%$ death of the brine shrimp compared to the stembark $(3.33 \pm 0.58)$ and the root $(3.33 \pm 0.58)$ with an average of $33.3 \%$ each respectively. The lethality observed in this extract was also found to be directly proportional to the extractives ranging from the lowest $(1 \mu \mathrm{g} / \mathrm{mL})$ to the highest $(500 \mu \mathrm{g} / \mathrm{mL})$, this concentration dependent increment in mortality rate of brine shrimp nauphii indicates cytotoxic principle in the extractives.

In table 3: The ethyl acetate leaves crude extract exhibited the lowest activity with $\mathrm{LC}_{50}$ value 2821.103 considering the fact that higher than $1000 \mu \mathrm{g} / \mathrm{mL}$ is nontoxic, thus caused a number of death of brine shrimp at an average of $10 \%$ while the fraction of stem-bark and roots exhibited the highest brine shrimp lethality with $\mathrm{LC}_{50}$ value $833.774 \mu \mathrm{g} / \mathrm{mL}$ when compared with the leaf, which caused a number of death of brine shrimp at $3.33 \pm 0.58 \mu \mathrm{g} / \mathrm{mL}$ or an average of $33.3 \%$ each respectively when compared to the report of Meyers, et al. [1], lower than $1000 \mu \mathrm{g} / \mathrm{mL}$ considered to be toxic, but this is rather weak-toxic when compared to the positive control thymol $1.16 \mu \mathrm{g} / \mathrm{mL}$.

The lethality concentration $\mathrm{LC}_{50}$ of the crude extracts in table 4 was assessed at $95 \%$ confidence using probit 


\section{International Journal of Biochemistry \& Physiology}

analysis it was observed that the leaf crude extracts showed cytotocity against brine shrimp with $\mathrm{LC}_{50}$ values of $3460 \mu \mathrm{g} / \mathrm{mL}$. This caused several deaths of brine shrimp at an average of $30 \%$ while the fraction of stembark and roots exhibited the highest toxicity value $813.96 \mu \mathrm{g} / \mathrm{mL}$ and $803.69 \mu \mathrm{g} / \mathrm{mL}$ which caused several deaths at an average of $43.3 \%$, however, it's a weaktoxic when compared to the toxicity evaluation of plant extracts by brine shrimp lethality bioassay $1000 \mu \mathrm{g} / \mathrm{mL}$ considered to be toxic.

In the brine shrimp test among extract evaluated in table 5, two of the fraction, the stem and roots crude extracts $\mathrm{LC}_{50}$ are less than $1000 \mu \mathrm{g} / \mathrm{mL}$ as well. $(992.985>1000 \mu \mathrm{g} / \mathrm{mL})$ thus exhibited weak toxicity when compared to the positive control the thymol $(1.16 \mu \mathrm{g} / \mathrm{mL})$ which exhibited a strong toxicity. The leaf crude extract was observed to be more toxic, the $\mathrm{LC}_{50}$ value of the extract was 651.292 lower than $1000 \mu \mathrm{g} / \mathrm{mL}$, however caused the death of brine shrimp at $1.33 \pm 0.73$ or an average of $13.3 \%$ at concentration $500 \mu \mathrm{g} / \mathrm{mL}$.

\section{Conclusion}

These extracts exhibited cytotoxic activity against brine shrimp. Hence, it is considered as containing active or potent components with $\mathrm{LC}_{50}$ values less than $1000 \mathrm{ppm}(\mu \mathrm{g} / \mathrm{mL})$. From this result, it is evident that the leaves, stem-bark and roots of the plant used in this study may have curative properties against several human pathogens as suggest its importance especially for extracts from ethyl acetate, chloroform and methanol,the results support the uses of these plant species in traditional medicine. This could as well be used in the synthesis of more useful drugs since the potent of its toxicity is mild.

\section{Statistical Analysis}

Each in vitro experiment was performed in triplicate and repeat three times. Experimental results were expressed as means \pm standard deviation (SD) of three parallel measurements with one-way ANOVA. The $\mathrm{LC}_{50}$ value for toxicity assay was calculated using the Probit Analysis option in the SPSS.

\section{Acknowledgement}

The authors are grateful for Kerenhappuch, Emmanuel, Helen-favour, Priscilia-Yashira for sample collection and ZAMALA UNIMAS for its support.

\section{Author's Contribution}

Isaac John Umaru: Design of experiment, data analysis, discussion and write of the manuscripts.
Fasihuddin A Badruddin: Coordinator and supervision of the research work.

Hauwa A. Umaru: Proof read of the manuscripts, Sample collection, and preparation of data analysis.

\section{Ethics}

This article is original and contains unpublished material. The corresponding author confirms no conflict of interest and all other authors have read and approved the manuscript. No ethical issues involved.

\section{References}

1. Meyer BN, Ferrigni NR, Putnam JE, Jacobsen LB, Nichols DE, et a. (1982) Brine shrimp: a convenient general bioassay for active plant constituents. Plant Med 45(5): 31-34.

2. Asaduzzaman $\mathrm{MD}$, Sohel rana $\mathrm{MD}$, Raqibul hasan SM, Monir Hossain MD, Nittananda D, et al. (2015) Cytotoxic (brine shrimp lethality bioassay) and antioxidant investigation of barringtonia acutangula (L.). International Journal of Pharma Sciences and Research 6(8): 1179-1185.

3. Rahman MS, Begum B, Chowdhury R, Rahman KM, Rashid MA, et al. (2008) Preliminary cytotoxicity screening of some medicinal plants of Bangladesh. Dhaka Univ J Pharm Sci 7(1): 47-52.

4. Bussmann RW, Malca G, Glenn A, Sharon D, Nilsen $B$, et al. (2011) Toxicity of medicinal plants used in traditional medicine in northern Peru. J Ethnopharm 137: 121-140.

5. Arcanjo DDR, Albuquerque ACM, Melo-Neto B, Santana LCLR, Medeiros MGF, et al. (2012) Bioactivity evaluation against Artemia salina L. each of medicinal plants used in Brazilian northeastern folk medicine. Braz J Biol 72(3): 505-509.

6. Biradi M, Hullatti K (2014) Screening of Indian medicinal plants for cytotoxic activity by brine shrimp lethality (BSL) assay and evaluation of their total phenolic content. Drug Dev Ther 5: 139-144.

7. Betti JL, Yemefa'a S RM, Nchembi Tarla F (2011) Contribution to the knowledge of non-wood forest products of the far north region of Cameroon: Medicinal plants sold in the Kousséri market. J Ecol Nat Environ 3(7): 241-254.

8. Ibrahim HA, Ali GY, Halliru SN, Usaini S, Abdullahi II (2012) Ethnobotanical Survey of the Wild Edible Food Plants Consumption among Local Communities in Kano State, North-Western, Nigeria. International Journal of Science and Technology 2(10): 713-717. 


\section{International Journal of Biochemistry \& Physiology}

9. Umaru IJ, Badruddin FA, Assim ZB, Umaru HA (2018) Antibacterial and Cytotoxic Actions of Chloroform Crude Extract of Leptadenia hastata (Pers) Decnee. Clin Med Biochemistry 4(1): 1-4.
10. Dambatta SH, Aliyu BS (2011) A survey of major ethno medicinal plants of Kano North Nigeria, their knowledge and uses by traditional healers. Bayero Journal of Pure and Applied Sciences 4(2): 28-34. 